KS. PIOTR KROCZEK

\title{
Czy można wypełnić dwa obowiązki podczas jednej mszy świętej?
}

W 2011 roku uroczystość Wniebowzięcia Najświętszej Maryi Panny przypadała w poniedziałek. Zarówno poprzedzająca niedziela, jak i wspomniany dzień świąteczny są dniami, w które wierni są zobowiązani uczestniczyć we mszy świętej, jak bowiem naucza Kościół - „ci, którzy dobrowolnie zaniedbują ten obowiązek, popełniają grzech ciężki”'.

W związku z tym zrodzić się może następujące pytanie: Czy uczestnicząc we mszy świętej w niedzielę wieczór, można uczynić zadość obowiązkowi uczestnictwa we mszy świętej w obydwie te uroczystości?

Niniejszy artykuł ma dać odpowiedź na tę kwestię. Ustosunkowanie się do niej ma charakter prospektywny, bowiem identyczna sytuacja, jak opisana powyżej, będzie miała miejsce w latach 2016, 2022, 2033 itd. Warto wspomnieć, że analogiczna sytuacja do przedstawionej, to znaczy, iż obowiązkowa uroczystość wypadnie w poniedziałek, będzie miała miejsce w przypadku np. uroczystości Narodzenia Pańskiego (25 grudnia) w latach 2017, 2023, 2028; uroczystości Bożej Rodzicielki Maryi (1 stycznia) w latach 2018, 2024, 2029; uroczystości Objawienia Pańskiego (6 stycznia) w latach 2014, 2020, 2025.

${ }^{1}$ Katechizm Kościoła katolickiego, 2181. 


\section{Regulacje prawne mające zastosowanie}

Wprawdzie, z zastrzeżeniem zawartym w kan. 2 Kodeksu prawa kanonicznego z 1983 roku ${ }^{2}$, kodeks zazwyczaj nie określa obrzędów, jakie należy zachować w sprawowaniu czynności liturgicznych, to jednak istnieje wiele norm kodeksowych odnoszących się do liturgii lub takich, które bezpośrednio regulują czynności liturgiczne. Trzeba zauważyć, że prawo ściśle liturgiczne (ius stricte liturgicum), czyli regulacje, które zawierają księgi liturgiczne ${ }^{3}$ oraz prawo dotyczące liturgii (ius in re liturgica), czyli unormowania zawarte w CIC $1983^{4}$ tworzą prawo liturgiczne (ius liturgicum $)^{5}$. Jest ono istotną częścią systemu prawa kanonicznego ${ }^{6}$.

To powiązanie liturgii i prawa kanonicznego jest więc bardzo silne, a można nawet powiedzieć, że jest ono organiczne ${ }^{7}$. Jak bowiem stanowi i poucza najwyższy prawodawca - czynności liturgiczne są to „czynności samego Kościoła” („,actiones Ecclesiae ipsius”, kan. $837 \$ 1)^{8}$. Liturgia, podobnie jak prawo kanoniczne, należą do istoty Kościoła, wyrażają jego

${ }^{2}$ Wszystkie cytowane kanony, o ile nie zaznaczono inaczej, odnoszą się do Codex Iuris Canonici auctoritate Ioannis Pauli PP. II promulgatus, „Acta Apostolice Sedis” 75 (1983) t. 2, s. 1-318; tekst łacińsko-polski, Poznań 1984; w zależności od wersji językowej są one cytowane $\mathrm{z}$ tych dwóch źródeł.

${ }^{3}$ Np. obowiązujące powszechnie takie jak np. Missale Romanum, Liturgia Horarum, Calendarium Romanum, Ordo celebrandi Martimonium, Ordo Confirmationis, Ordo Poenitentiea czy obowiązujące partykularnie, takie jak kalendarz liturgiczny diecezji lub instytutu życia konsekrowanego.

${ }^{4}$ Np. kan. 835, kan. 861, kan. 883, kan. 864, kan. 889, kan. 912, kan. 850, kan. 877, kan. 961.

${ }^{5}$ Szeroko o prawie liturgicznym pisze: J. Nowak, Prawo $w$ służbie wydarzeń zbawczych. Zarys prawodawstwa liturgicznego, Poznań 2004.

${ }^{6}$ P. Kroczek, The Art of Legislation: the Principles of Lawgiving in the Church, Kraków 2011, s. 105 (oczywiście, nie można pominąć prawa zwyczajowego, które w Kościele jest pełnoprawnym źródłem norm, także liturgicznych).

7 Tak było nota bene od początku Kościoła, zob. 1 Tm 2, 8; 1 Tm 2, 11-15; na ten temat pisze: R. F. Collins, The Origin of Church Law, „The Jurist” 61 (2001), s. 135.

${ }^{8}$ Zob. L. Gerosa, Prawo Kościoła, przeł. I. Pękalski, Poznań 1999, s. 100-101. 
naturę i nie mogą być od Kościoła oddzielone (zob. Sobór Watykański II, konst. Sacrosanctum Concilium, 2. 10) ${ }^{9}$.

Aby więc znaleźć odpowiedź na postawione na początku artykułu pytanie badawcze, należy zwrócić się ku stosownym przepisom. Kluczowe dla omawianego zagadnienia są dwa kanony: 1247 i $1248 \$ 1$. Pochodzące $\mathrm{z}$ nich normy jako zrębowe regulują badaną kwestię. Trzeba przedstawić treść tych norm oraz zwrócić uwagę na normy pochodzące $\mathrm{z}$ innych ustaw kościelnych, które mają charakter modyfikujący normy podstawowe.

\subsection{Norma pierwsza}

Zgodnie z kan. $1247^{10}$ wierni są zobowiązani uczestniczyć we mszy świętej w niedzielę oraz w inne dni świąteczne nakazane (por. Sobór Watykański II, konst. Sacrosanctum Concilium, 106). Ten obowiązek rozszerzony został w drugim zdaniu tego kanonu o wymóg powstrzymania się od wykonywania tych prac i zajęć, które utrudniają oddawanie Bogu czci, przeżywanie radości właściwej dniu Pańskiemu oraz korzystanie z należnego odpoczynku duchowego i fizycznego. W optyce tego artykułu znajduje się tylko pierwszy z wymienionych nakazów ${ }^{11}$.

Analizowany kanon należy do ustaw czysto kościelnych (leges mere ecclesiasticae). Dlatego obowiązkiem wypływającym z niego objęci są ochrzczeni w Kościele katolickim lub do niego przyjęci (zob. kan. 204

${ }^{9}$ Zob. Joannes Paulus PP. II, Constitutio Apostolica Sacrae disciplinae leges Codex Iuris Canonici promulgatur, „Acta Apostolice Sedis” 75 (1983) t. 2, s. XI.

${ }^{10}$ Kan. 1247: „Die dominica aliisque diebus festis de praecepto fideles obligatione tenentur Missam participandi; abstineant insuper ab illis operibus et negotiis quae cultum Deo reddendum, laetitiam diei Domini propriam, aut debitam mentis ac corporis relaxationem impediant”. „W niedzielę oraz w inne dni świąteczne nakazane, wierni są zobowiązani uczestniczyć we Mszy świętej oraz powstrzymać się od wykonywania tych prac i zajęć, które utrudniają oddawanie Bogu czci, przeżywanie radości właściwej dniowi Pańskiemu oraz korzystanie z należnego odpoczynku duchowego i fizycznego”.

${ }^{11} \mathrm{Na}$ temat obowiązku spoczynku w dniu świątecznym, zob. P. Kroczek, Świętowanie w pedagogice prawa kanonicznego i prawa polskiego, „Polonia Sacra” 28 (2011) nr 72, s. $173-174$. 
i 205), którzy jednak posiadają wystarczające używanie rozumu oraz ukończyli siódmy rok życia (kan. 11). Oczywiście ustawa ta ma swoją genezę nie tylko w woli prawodawcy powszechnego, lecz w pozytywnym prawie Bożym, w III przykazaniu Bożym² ${ }^{12}$.

Odnosząc się do treści obowiązku zawartego w przedstawionym kanonie, trzeba powiedzieć, że uczestniczenie we mszy świętej minimalistycznie ujęte oznacza fizyczną obecność i świadomość czynności, jaką się wykonuje $\mathrm{e}^{13}$. Zwrócić jednak należy uwagę na to, że ta czynność jest określona w Codex Iuris Canonici z 1983 roku czasownikiem „participare”, zaś w analogicznym do omawianego kan. 1248 w Codex Iuris Canonici z 1917 roku $^{14}$ było użyte przez prawodawcę słowa „audire”. Można zakładać, że prawodawcy chodziło o to, aby uczestnictwo wiernych we mszy świętej nie było bierne, ale aktywne. Takie rozumowanie jest zgodne z nauczaniem Soboru Watykańskiego II. W Konstytucji o liturgii świętej Sacrosanctum Concilium ${ }^{15}$ znajduje się czytelne wezwanie, aby uczestnictwo wiernych w obrzędach było „świadome, czynne i owocne” („scienter, actuose et fructuose", zob. np. nr 11, 14, 19, 27), takiego uczestnictwa bowiem domaga się sama natura liturgii ( $\mathrm{nr} 14)$.

Pragnąc określić dzień, w którym należy wypełnić przedstawiony wyżej obowiązek, trzeba powiedzieć, że prawo kanoniczne nakazuje traktowanie niedzieli jako dnia świątecznego w kan. $1246 \$ 1$ : „Dies dominica in qua mysterium paschale celebratur, ex apostolica traditione, in universa Ecclesia uti primordialis dies festus de praecepto servanda est" ${ }^{16}$.

${ }^{12}$ Zob. dwie wersje Dekalogu: Wj 20, 2-17 oraz Pwt 5, 6-21.

${ }^{13}$ J. M. Huels, Ad can. 1247, [w:] New Commentary on the Code of Canon Law, ed. by J. P. Beal, J. A. Coriden, T. J. Green, New York-Mahwah 2000, s. 1445.

${ }^{14}$ Codex Iuris Canonici. Pii X Pontificis Maximi iussu digestus, Benedicti Papae XV auctoritate promulgatus, 27 V 1917, „Acta Apostolice Sedis” 9 (1917) t. 2, s. 11-456.

${ }^{15}$ Sacrosanctum Concilium Oecumenicum Vaticanum II, Constitutio Sacrosanctum Concilium de Sacra Liturgia, 4 XII 1963, „Acta Apostolice Sedis” 56 (1964), s. 97-138; tekst łacińsko-polski: Sobór Watykański II, Konstytucja o liturgii świętej Sacrosanctum Concilium, [w:] Sobór Watykański II, Konstytucje, dekrety, deklaracje, Poznań 1986, s. 25-99.

${ }^{16}$ Kan. 1246: „Niedziela, w czasie której jest czczona tajemnica paschalna, na podstawie tradycji apostolskiej winna być obchodzona w całym Kościele jako najdawniejszy 
Papież Jan Paweł II przypomniał o tej prawdzie w liście apostolskim Dies Domini $^{17}$, którego celem nota bene było przynaglenie do zachowania świątecznego charakteru niedzieli.

Kolejnymi dniami określanymi jako świąteczne nakazane są dni związane z najważniejszymi dogmatami katolickiej wiary lub wydarzeniami $\mathrm{z}$ historii zbawienia. Ich wyliczenie zawiera kan. $1246 \$ 1$ (por. Codex Iuris Canonici z roku 1917, kan. 1247 \$ 1). Są to następujące dni świąteczne: Narodzenia Pana naszego Jezusa Chrystusa, Objawienia Pańskiego, Wniebowstąpienia Pańskiego, Najświętszego Ciała i Krwi Chrystusa, Świętej Bożej Rodzicielki Maryi, Jej Niepokalanego Poczęcia i Wniebowzięcia, Świętego Józefa, Świętych Apostołów Piotra i Pawła, a także Wszystkich Swiętych. Ten spis nie jest ani kompletny, ani ostateczny, bowiem w kan. $1244 \$ 1$ prawodawca stanowił, że choć wprawdzie ustanawianie dni świątecznych wspólnych w całym Kościele, ich przenoszenie i znoszenie należy do wyłącznej kompetencji najwyższej władzy kościelnej, to jednak należy zachować normę z kan. $1246 \$ 2$, która przyznaje Konferencji Episkopatu kompetencje do zniesienia lub przeniesienia niektórych z dni świątecznych nakazanych na niedzielę, jednakże za uprzednią aprobatą Stolicy Apostolskiej. Dodatkowo należy pamiętać, że biskupi diecezjalni mogą, lecz tylko w pojedynczych wypadkach, wyznaczać poszczególne dni świąteczne dla swoich diecezji albo miejsc (kan. $1244 \$ 2$ ).

Chcąc podać autorytatywne miejsce, w którym znajdują się wszystkie obowiązujące powszechnie, czyli adresowane do całego Kościoła katolickiego we wszystkich obrządkach dni świąteczne, trzeba wymienić Ogólne normy roku liturgicznego i kalendarza ${ }^{18}$ oraz Calendarium Romanum generale $^{19}$. Modyfikacje tych wykazów dostosowane do Kościoła lokalnego

dzień świąteczny nakazany".

${ }^{17}$ Joannes Paulus PP. II, Epistula Apostolica Dies Domini de Dei Dominicae sanctificatione, „Acta Apostolice Sedis” 90 (1998), s. 713-766.

${ }^{18}$ Ogólne normy roku liturgicznego i kalendarza, 21 III 1969, [w:] Mszał rzymski dla diecezji polskich, wyd. 2 poszerzone, Poznań 2009, s. [77]-[85].

${ }^{19}$ Calendarium Romanum ex Decreto Sacrosancti Oecumenici Concilii Vaticani II instauratum auctoritate Pauli PP VI promulgatum, Editio typica, Rome 1969. Ogólny kalendarz liturgiczny jest co roku publikowany, zob. np. Ordo Missae Celebrandae et 
lub rodziny zakonnej zawiera ich własny kalendarz ${ }^{20}$. Są to obchody o zasięgu ograniczonym do kościoła lokalnego lub rodziny zakonnej wkomponowane w cykl ogólny ${ }^{21}$.

\subsection{Norma druga}

„Praecepto de Missa participanda satisfacit qui Missae assistit ubicumque celebratur ritu catholico vel ipso die festo vel vespere diei praecedenti”22 - tak stanowi prawodawca w kan. $1248 \$ 1$. Wprawdzie kanon ten nie ma odpowiednika w Codex Iuris Canonici z roku 1917²3, to jednak takie rozwiązanie w postaci mszy świętej wieczornej nie jest nowe $^{24}$. Wcześniej specjalne pozwolenie na taką mszę świętą antycypującą następny dzień świąteczny miały niektóre rejony kościelne (np. Niemcy, Szwajcaria, Francja, USA) ${ }^{25}$. Dlatego też Święta Kongregacja Kultu Bożego w instrukcji Eucharisticum mysterium ${ }^{26}$, nr 28 stwierdziła że: „Sicubi ex concessione Apostolicae Sedis permittitur ut vespere sabbati praecedentis satisfieri possit praecepto de Missa participanda die dominica, pastores

Divini officii persolvendi. Secundum Calendarium Romanum Generale. Pro anno liturgico 2010-2011, Vatican 2010.

${ }^{20}$ Ogólne normy roku liturgicznego i kalendarza, 48; zob. przykładowo: Kalendarz liturgiczny archidiecezji katowickiej, Katowice 2011, czy Kalendarz liturgiczny polskich prowincji Towarzystwa Jezusowego na rok 2012, Kraków 2011.

${ }^{21}$ Tak to definiuje dokument Ogólne normy roku liturgicznego i kalendarza, 49.

${ }^{22}$ Kan. $1248 \$ 1$ : „Nakazowi uczestniczenia we mszy świętej czyni zadość ten, kto bierze w niej udział, gdziekolwiek jest odprawiana w obrządku katolickim, bądź w sam dzień świąteczny, bądź też wieczorem dnia poprzedzającego".

${ }^{23} \mathrm{~W}$ tym kodeksie w kan. 821 par. 1 zakazywał rozpoczęcia sprawowania mszy świetej.

${ }^{24}$ Przebieg dyskusji teologicznej i jej wpływ na normy liturgiczne referuje Jarosław Superson w artykule: Świętowanie niedzieli przez udział w Eucharystii (panorama historyczna), „Ruch Biblijny i Liturgiczny” 62 (2009) nr 3, s. 174-181.

${ }^{25}$ Szeroko tę sprawę referuje bp Stefan Cichy w artykule Rozpoczęcie świętowania niedzieli w sobotę, „Ruch Biblijny i Liturgiczny” 43 (1990) nr 1-2, s. 36-38.

${ }^{26}$ Sacra Congregatio Rituum, Instructio Eucharisticum mysterium de cultu Mysterii Eucharistici, 25 V 1967, „Acta Apostolice Sedis” 59 (1967), s. 556-573. 
sedulo doceant fideles de significatione huius concessionis, et cfurent ne sensus diei dominicae exinde aliquomodo obscuretur"27. Wydała przy tym stosowne zarządzenia, które miały zapewnić zachowanie świątecznego charakteru niedzieli ${ }^{28}$. Normy te zostały powtórzone i uszczegółowione we wskazaniach tejże kongregacji w 1974 roku, przedstawionych w dokumencie De Missa diei dominicae et festi de praecepto vespere diei praecedentis anticipata $^{29}$.

Pytanie, jakie należy w tym miejscu postawić, dotyczy określenia czasu, w jakim msza święta powinna być sprawowana, aby można było zadośćuczynić obowiązkowi. Można je sformułować następująco: Jaki jest zakres znaczeniowy pojęcia „wieczorem” („vespere”)?

$\mathrm{Z}$ pewnością termin ten można uznać za niejasny. Należy więc go dookreślić ${ }^{30}$. Szukając odpowiedzi na to pytanie, trzeba zwrócić uwagę na to, że po raz pierwszy na mszę świętą wieczorną, lecz nie antycypującą dzień następny, zezwolił papież Pius XII w Konstytucji apostolskiej Christus Dominus z 1953 roku³1. Zaznaczono wówczas, że msza święta

27 „Jeżeli za zgodą Stolicy Apostolskiej zezwolono gdzieś na wypełnienie przykazania o uczestnictwie we mszy świętej niedzielnej wieczorem w uprzednią sobotę, to pasterze powinni dokładnie pouczyć wiernych o sensie tego zezwolenia i zatroszczyć się, by świadomość dnia niedzielnego nie zatarła się przez to żadną miarą”. Przykładem takiego pozwolenia jest indult udzielony diecezjom w USA przez Sacra Congregatio pro Clericis z 10 stycznia 1970 na okres 5 lat, zob. The Canon Law Digest: Officially Published Documents Affecting the Code of Canon Law 1968-1972, t. 7, ed. by J. I. O'Connor, Chicago 1975, s. 778-779.

${ }^{28}$ Instructio Eucharisticum mysterium de cultu Mysterii Eucharistici, 28.

${ }^{29}$ Sacra Congregatio pro Cultu Divino, De Missa diei dominicae et festi de praecepto vespere diei praecedentis anticipata, „Notitiae: commentarii ad nuntia et studia de re liturgica” 11 (1974), s. 222-223.

${ }^{30} \mathrm{Na}$ temat zwrotów niedookreślonych i nieostrych oraz sposobów postępowania z nimi w procesie interpretacji zob. P. Kroczek, Niedookreśloność i nieostrość zwrotów w prawie kanonicznym na przykładzie KPK z 1983 r., „Annales Canonici” 1 (2005), s. 175-185.

${ }^{31}$ Pius PP. XII, Constitutio Apostolica Christus Dominus de disciplina servanda quoad ieiunium Eucharisticum, 6 I 1953, „Acta Apostolice Sedis” 45 (1953), s. 15-24. 
wieczorna nie może rozpoczynać się przed godziną $16^{32}$. Ta właśnie godzina to zgodnie $\mathrm{z}$ regulacjami Kościoła rozpoczyna wieczór, a kończy „popołudnie” („post meridiem”). Tak więc „wieczór” to czas po godzinie 16 do początku nowego dnia ${ }^{33}$.

Liturgicznie podchodząc do zagadnienia czasu mszy świętej wieczornej, należy stwierdzić, że antycypująca msza święta nie powinna rozpoczynać się przed odprawieniem pierwszych nieszporów uroczystości dnia następnego. Nieszpory są wieczorną modlitwą. Pora wieczorna w liturgii rozumiana jako „czas, w którym dzień już się kończy”34.

Prostsza sprawa jest z wyrażeniem „dzień” („dies”) z analizowanego kanonu. Zgodnie bowiem z kan. $202 \$ 1$ „dzień w prawie oznacza stały czasokres obejmujący 24 kolejno liczone godziny i zaczyna się od północy”.

W analizie omawianego przepisu ważne jest, aby zwrócić uwagę na liczbę pojedynczą w rzeczowniku „msza święta” („missa”). Gdyby prawodawcy chodziło o zachowanie wiernego, w którym musiałby tyle razy uczestniczyć we mszy świętej, ile istnieje obowiązków wypływających z liczby dni, to z pewnością użyłby liczby mnogiej. Wówczas oczywiste by było, że tyle, ile istnieje obowiązków wypływających z liczby dni, tyle razy wierny musi uczestniczyć we mszy świętej.

Msza święta może być sprawowana w każdym katolickim rycie jakiegokolwiek katolickiego Kościoła sui iuris. Należy zwrócić uwagę, że może to być wyłącznie Kościół posiadający pełną komunię z Kościołem katolickim $^{35}$. Ofiara eucharystyczna może być sprawowana przy użyciu

${ }^{32}$ Tamże, VI.

${ }^{33}$ Szerzej na ten temat: J. Hules, T. Willis, What Time for Anticipated Masses?, „Emmanuel” 96 (1990), s. 31-41.

${ }^{34}$ Ogólne wprowadzenie do Liturgii Godzin, 39 [w:] Liturgia Godzin. Codzienna modlitwa ludu Bożego, t. 1, Okres adwentu. Okres Bożego Narodzenia, Poznań 1982, s. 43.

${ }^{35}$ Poprzednie Dyrektorium Ekumeniczne z roku 1967 zezwalało na wypełnienie obowiązku uczestnictwa we mszy świętej poprzez udział w liturgii w Kościołach prawosławnych - zob. Secretariatus ad Christianorum Unitatem Fovendam, Directorium Ad totam Ecclesiam ad ea quae a Concilio Vaticano Secundo de re oecumenica promulgata sunt exsequenda, pars prima, 47, „Acta Apostolice Sedis” 59 (1967), s. 574-592. Ten przywilej został zniesiony w roku 1993 poprzez dokument Pontificium Consilium ad Unitatem 
jakichkolwiek zatwierdzonych tekstów liturgicznych, czyli dowolnego formularza mszalnego i dowolnych czytań mszalnych ${ }^{36}$.

Wynika $\mathrm{z}$ tego, że w omawianym przypadku możliwe jest sprawowanie mszy świętej zarówno przy użyciu tekstów liturgicznych z niedzieli, która przypada w dniu, w którym wierny uczestniczy we mszy albo też dnia świątecznego, którego wigilię tej niedzieli się obchodzi. Zaleca się jednak, aby była to msza święta niedzielna ${ }^{37}$. W takich wypadkach należy odprawić mszę świętą tak, jak wyznacza ją kalendarz na niedzielę, nie wykluczając homilii i modlitwy wiernych ${ }^{38}$. Trzeba zauważyć, że w przeddzień uroczystości takich jak Narodzenie Pańskie, Zesłanie Ducha Świętego, Narodzenie św. Jana Chrzciciela, Świętych Apostołów Piotra i Pawła oraz Wniebowzięcia Najświętszej Maryi Panny należy użyć formularza z tychże uroczystości ${ }^{39}$. Trzeba w tym miejscu przywołać zdanie Kongregacji Kultu Bożego, która wyraziła opinię, że podczas tej samej celebracji część wiernych

Christianorum Fovendam, Directoire pour l'application des principes et des normes sur l’oecuménisme, 25 III 1993, 115, „Acta Apostolice Sedis” 85 (1993), s. 1039-1119. Niektórzy autorzy piszą, że został on zniesiony przez wejście w życie Kodeksu prawa kanonicznego z roku 1983, bowiem kan. 1247 nic nie wspomina o tym przywileju ani nie dopuszczał wyjątków - zob. J. M. Huels, Ad kan. 1247, [w:] New Commentary on the Code of Canon Law, ed. by J. P. Beal, J. A. Coriden, T. J. Green, New York-Mahwah 2000, s. 1445.

${ }^{36}$ Sacra Congregatio pro Clericis, Responsum, 3 IV 1971, Prot. N. 134238/1, The Canon Law Digest: Officially Published Documents Affecting the Code of Canon Law19821983, t. 10, Chicago 1986, ed. by J. I. O’Connor, s. 190.

${ }^{37}$ Sacra Congregatio pro Cultu Divino, De Missa diei dominicae et festi de praecepto vespere diei praecedentis anticipata, „Notitiae: commentarii ad nuntia et studia de re liturgica” 11 (1974), s. 223; Sacra Congregatio pro Cultu Divino, De calendario liturgico exarando pro anno 1985-1985, „Notitiae: commentarii ad nuntia et studia de re liturgica” 20 (1984), s. 603-605.

${ }^{38}$ Instructio Eucharisticum mysterium de cultu Mysterii Eucharistici, 28.

${ }^{39}$ Sacra Congregatio pro Cultu Divino, De Missa diei dominicae et festi de praecepto vespere diei praecedentis anticipata, „Notitiae: commentarii ad nuntia et studia de re liturgica” 11 (1974), s. 223. 
może wypełniać obowiązek uczestnictwa w dniu bieżącym, a część wiernych wypełnia obowiązek obejmujący dzień następny ${ }^{40}$.

Wypada jeszcze dodać, że choć obowiązek uczestnictwa we mszy świętej wypełnić można w dzień poprzedni, to obowiązek odpoczynku obowiązuje tylko w dzień ściśle określony w kalendarzu liturgicznym i nie można go przenieść na inny dzień ${ }^{41}$.

\section{Propozycje interpretacji i aplikacji norm}

Przedstawione normy można interpretować i aplikować na dwa sposoby.

\subsection{Rozwiązanie pierwsze}

Rozwiązanie pierwsze można oprzeć na wykładni językowej omawianych przepisów. Ten rodzaj interpretacji w pierwszej kolejności opiera się na językowych regułach interpretacji, a więc polega na wydobyciu normy poprzez badanie etymologii słów użytych w przepisie lub przepisach, posługując się zasadami semantyki, syntaktyki i gramatyki. W omawianej sprawie rezultatem będzie wykładnia ${ }^{42} \mathrm{w}$ postaci normy, która dopuszcza sytuację, aby uczestnicząc we mszy świętej wieczornej jednocześnie wypełnić dwa obowiązki. Na pytanie postawione we wstępie trzeba więc odpowiedzieć: positive. Wierny, uczestnicząc we mszy świętej w niedzielę wieczór, może uczynić zadość obowiązkowi uczestnictwa we mszy świętej w niedzielę i następującej po niej uroczystości.

${ }^{40}$ Sacra Congregatio pro Cultu Divino, De Missa diei dominicae et festi de praecepto vespere diei praecedentis anticipata, „Notitiae: commentarii ad nuntia et studia de re liturgica” 11 (1974), s. 222-223.

${ }^{41}$ Zob. Pontificia Commissio Codici Iuris Canonici Recognoscendo, Canon 44, „Communicationes” 12 (1980) nr 2, s. 359.

${ }^{42} \mathrm{~W}$ zależności od kontekstu słownego wyraz „wykładnia” oznacza bądź to zespół pewnych czynności odnoszących się do jakichś wyrażeń lub też wynik tych czynności - por. M. Zieliński, Wykładnia prawa. Zasady. Reguły. Wskazówki, Warszawa 2002, s. 45-46. 
Argumentem przemawiającym za takim rozwiązaniem jest to, że w przypadku, gdy w niedzielę przypadnie jakaś uroczystość, to nie istnieje obowiązek dwukrotnego uczestniczenia we mszy świętej.

Można również przytoczyć argument za słusznością tego rozwiązania wypływający z tego, że zgodnie z zasadą zawartą w Kodeksie prawa kanonicznego z roku 1983 kan. 18, czyli „Odia restringi, et favores convenit ampliari” (por. Codex Iuris Canonici z roku 1917 kan. 19) ${ }^{43}$, należy unikać niepotrzebnego obarczania wiernych ciężarami, które nie muszą koniecznie być przez nich wypełniane.

\subsection{Rozwiązanie drugie}

Jest możliwa i inna wykładnia oparta na interpretacji teleologicznej, czyli takiej, która szuka znaczenia przepisu lub przepisów, odpowiadając na pytanie o sens istnienia regulacji, stara się odczytać jej zadania i pożądany przez prawodawcę kierunek działania. Jej podstawą jest cel wydania ustawy, czyli ratio legis.

Celem obowiązku przedstawionego w analizowanych kanonach jest uczczenie dnia świątecznego. Dlatego też jeżeli są dwa dni świąteczne, istnieją dwa obowiązki. To, że okazjonalnie wypadają obok siebie, nie zmienia faktu, że każdy z tych dni stwarza po stronie katolika obowiązek uczestnictwa we mszy świętej, jako formie świętowania. Dlatego należy na pytanie postawione we wstępie odpowiedzieć: negative. Wierny, uczestnicząc we mszy świętej w niedzielę wieczór, nie może uczynić zadość obowiązkowi uczestnictwa we mszy świętej w niedzielę i następującej po niej uroczystości.

Wydaje się natomiast, że możliwa jest także sytuacja, gdy wierny będzie uczestniczył dwa razy we mszy świętej w tym samym dniu, to znaczy w ciągu dnia świątecznego poprzedzającego inny dzień świąteczny. Uczyni w ten sposób zadość obowiązkowi dnia bieżącego i wieczorem zadość obowiązkowi dnia następnego.

${ }^{43}$ Por. Bonifatius PP. VIII, De regule iuris, 3 III 1298, 15, [w:] Corpus Iuris Canonici, t. 2, Lipsiae 1881, kol. 1122-1124. 


\section{Wnioski i postulaty de lege ferenda}

Żadne z podanych powyżej rozwiązań nie jest jako jedyne pewne i poprawne. W konsekwencji wydaje się, że słuszne jest twierdzenie, iż oba rozwiązania są dopuszczalne i można zarysowany problem rozwiązać na dwa sposoby w zależności od preferencji osoby dokonującej interpretacji ${ }^{44}$.

Jednak stanowisko dopuszczające oba rozwiązania jako dwa równouprawnione z praktycznego, czyli duszpasterskiego punktu widzenia jest wielce niekorzystne. Z pewnością sytuacja, w której część duszpasterzy opowiada się za rozwiązaniem pierwszym, a część za drugim, nie jest dobra z punktu widzenia promowania jedności praktyk religijnych w Kościele. Trzeba pamiętać, że „liturgia nie jest nigdy prywatną własnością kogokolwiek, ani celebransa, ani wspólnoty, w której jest sprawowana tajemnica. [...] Również w naszych czasach posłuszeństwo normom liturgicznym powinno być na nowo odkryte i docenione jako odbicie i świadectwo Kościoła jednego i powszechnego, uobecnionego w każdej celebracji Eucharystii. Kapłan, który wiernie sprawuje mszę świętą według norm liturgicznych, oraz wspólnota, która się do nich dostosowuje, ukazują w sposób dyskretny, lecz wymowny swą miłość do Kościoła"45.

Bez zachowania tej jedności w liturgii podważany jest autorytet biskupa diecezjalnego, który przecież zgodnie z prawem jest odpowiedzialny za kierowanie świętą liturgią (kan. $838 \$ 1$ ) i w ramach przysługującej mu kompetencji może on wydawać ustawy w sprawach liturgicznych, które obowiązują wszystkich będących pod jego zwierzchnictwem (kan. 838 $\$ 4)$. Biskup diecezjalny powinien więc zawczasu takie sytuacje przewidzieć i dać jasną wykładnię wiernym, czego się od nich oczekuje. Jest to

${ }^{44}$ Por. J. M. Huels, Canon 1248. Double Precept fufilled at One Mass, [w:] CLSA Advisory Opinions 1984-1993, ed. by P. J. Cogan, Washington 1995, s. 398.

${ }^{45}$ Jan Paweł II, Encyklika Ecclesia de Eucharistia do biskupów, do kapłanów i diakonów, do zakonników i zakonnic, do katolików świeckich oraz do wszystkich ludzi dobrej woli o Eucharystii w życiu Kościoła, Warszawa 2003, nr 52; wersja oryginalna: Joannes Paulus PP. II, Litterae encyclicae Ecclesia de Eucharistia de Eucharistia eiusque necessitudine cum Ecclesia, „Acta Apostolice Sedis” 95 (2003), s. 433-475. 
jego obowiązkiem, bowiem wierny, który jest związany normami prawa kanonicznego, ma prawo wiedzieć, jak ma się zachować.

Taki postulat skierowany do kompetentnego przełożonego kościelnego jest bardzo ważny, prawo kanoniczne bowiem obowiązuje wiernych w sumieniu. Ustawa kościelna rodzi obowiązek wobec samego Boga ${ }^{46}$. Reguły postępowania nakazane przez prawo wspólnoty wiernych to sposób praktykowania wiary. Zasadniczo można powiedzieć, że kto nie przestrzega regulacji prawa kanonicznego, ten grzeszy ${ }^{47}$. Przepisy kanoniczne są uporządkowaniem zasad, które wierni będą zachowywać nie tylko ze względu na możliwość grożącej im sankcji, ale także, co do których wymagań, jak się oczekuje, wierni będą pozytywnie nastawieni, ich wiara bowiem będzie nakazywała im uczynić zadość obowiązkowi ze względu na dobro i wartości, jakie norma niesie ${ }^{48}$.

Należy więc znaleźć jasne rozwiązanie badanej kwestii. Można w poszukiwaniu oprzeć się na fakcie, iż w badanej sprawie należy mówić o wątpliwości, czyli zawieszeniu pomiędzy dwoma zdaniami przeciwnymi, za którymi stoją pewne argumenty. Istnieje więc tu sytuacja wątpliwości prawnej („dubium iuris”), w której zgodnie z kan. 14 prawo nie obowiązuje $^{49}$.

W konkretnym przypadku jest pewne, że wierny musi uczestniczyć we mszy świętej w związku z obowiązkiem wywołanym dniem świątecznym, lecz może zadośćuczynić temu obowiązkowi wieczorem dnia poprzedzającego tę uroczystość. Nie jest natomiast pewne, czy dany badany życiowy przypadek podpada pod obowiązek uczestnictwa w drugim dniu świątecznym. A skoro tak, to zgodnie z zasadą „lex dubia non obligat" norma kan. 1247 w drugim dniu świątecznym, czyli jakby ipsa

${ }^{46}$ G. Michiels, Normae generales iuris canonici, t. 1, Parisiis-Tornaci-Romae 1949, s. 290.

${ }^{47}$ R. Sobański, Nauki podstawowe prawa kanonicznego, t. 1, Teoria prawa kanonicznego, Warszawa 2001, s. 106nn.

${ }^{48}$ Zob. J. A. Selling, Law and Values: Clarifying the Relationship between Canon Law and Moral Theology, „The Jurist” 56 (1996) nr 1, s. 92-110.

${ }^{49}$ R. Sobański, Ad kan. 14, [w:] J. Krukowski, R. Sobański, Komentarz do Kodeksu Prawa Kanonicznego, t. 1, Księga I. Normy ogólne, red. J. Krukowski, Poznań 2003, s. 65. 
die nie obowiązuje i wierny nie musi uczestniczyć w drugim dniu świątecznym we mszy świętej ${ }^{50}$.

Dobrym rozwiązaniem byłaby autentyczna interpretacja dokonana przez prawodawcę lub przez tego, komu zlecił on takie zadanie (kan. 16 $\$ 1)$. Obecnie kompetencje taką mają, poza biskupem Rzymu, także kolegium biskupów z papieżem jako głową (kan. 331 i 336) oraz Papieska Rada do spraw Tekstów Prawnych (Pontificium Consilium de Legum Textibus). W niektórych przypadkach o charakterze deklaratywnym interpretacji takiej mogą dokonywać kongregacje rzymskie zgodnie $\mathrm{z}$ kan. $31-34^{51}$.

Wydaje się, że innym słusznym rozwiązaniem przedstawionego problemu byłaby dyspensa udzielona przez biskupa diecezjalnego od obowiązku uczestnictwa we mszy świętej (zob. kan. $87 \$ 1$ ). Przy zachowaniu ich prawa taką dyspensę może również udzielić zgodnie z kan. 1245 proboszcz dla słusznej przyczyny i według przepisów biskupa diecezjalnego. Może on także dokonać zamiany tego obowiązku na inne uczynki pobożne. Taką samą kompetencję jak proboszcz ma przełożony kleryckiego instytutu zakonnego lub stowarzyszenia życia apostolskiego na prawie papieskim w odniesieniu do swoich podwładnych oraz innych osób przebywających na stałe w domu. W przypadku świąt obowiązujących lokalnie, czyli ustanowionych jako dni obowiązkowe przez lokalnego biskupa, taką władzę dyspensowania ma zgodnie z kan. 88 również ordynariusz miejsca. Oczywiście zawsze musi być to pożyteczne dla duchowego dobra wiernych i musi istnieć słuszna i racjonalna przyczyna z uwzględnieniem okoliczności przypadku i ważności ustawy, która motywuje do udzielenia dyspensy. W przeciwnym razie dyspensa jest niegodziwa, a także jest nieważna. Wydaje się, że takim powodem do udzielenia może być, przykładowo, znaczna odległość od kościoła czy bardzo trudne warunki pogodowe.

Trzeba pamiętać, że nie tylko dyspensa może zwolnić z obowiązku zachowania dnia świątecznego. W teologii moralnej i prawie kanonicznym

${ }^{50}$ J. M. Huels, Canon 1248. Double Precept fufilled at One Mass, [w:] CLSA Advisory Opinions 1984-1993, ed. by P. J. Cogan, Washington 1995, s. 398.

${ }^{51}$ Więcej o autentycznej interpretacji zob. P. Kroczek, The Art of Legislation: the Principles of Lawgiving in the Church, Kraków 2011, s. 235 i podana tam literatura. 
istnieje instytucja epiki (epiéikeia) ${ }^{52}$. Jej zasadą jest to, iż wierny będąc zobowiązany abstrakcyjną normą, która przecież nie może uwzględnić wszystkich sytuacji indywidualnych, konkretyzuje ją w swoim poszczególnym przypadku i może dojść do wniosku, że ta norma nie obowiązuje go w danej sytuacji. Wówczas nieprzestrzeganie normy nie jest czymś niegodziwym, czyli sprzecznym z nakazem wiążącym w sumieniu, ponieważ nie wypływa $z$ chęci uwolnienia się od prawa i jego ciężarów, lecz jest korektą normy prawa w duchu prawodawcy. Odstąpienie od norm ustawy nakazuje rozum ze względu na sprawiedliwość, jaka mogła być naruszona przez zachowanie ustawy ${ }^{53}$.

Innym sposobem rozwiązania omawianego problemu, trzeba dodać - praktycznym - jest jasne wyjaśnienie zaistniałej sytuacji i udzielenie jednoznacznej odpowiedzi wiernym poprzez regulacje w kalendarzu liturgicznym kościoła partykularnego (zob. kan. $838 \$ 4$ ) lub list pasterski biskupa diecezjalnego skierowany do wiernych ${ }^{54}$.

\section{Abstrakt}

Problem tego artykułu może być zawarty pytaniu: czy wierny może wypełnić dwa obowiązki uczestniczenia we mszy świętej podczas jednej mszy świętej? Regulacje prawne, które mają zastosowanie przy udzieleniu odpowiedzi na to pytanie to głównie kan. 1247 i kan. $1248 \$ 1$ z KPK 1983. Rozwiązując wskazany problem należy podać wykładnię tych przepisów. Wniosek z rozważań jest następujący: chociaż prawo pozwala na

${ }^{52}$ Szeroko o tym zob. G. Virt, Epikie - verantwortlicher Umgang mit Normen: eine historisch-systematische Untersuchung zu Aristoteles, Thomas von Aquin und Franz Suarez, Mainz 1983.

${ }^{53}$ Szerzej zob. R. Sobański, Nauki podstawowe prawa kanonicznego, t. 1 Teoria prawa kanonicznego, Warszawa 2001, s. 130-133.

${ }^{54} \mathrm{O}$ znaczeniu i formach należytego pouczenia wiernych w tej sprawie zob. np. S. Cichy, Rozpoczęcie świętowania niedzieli w sobotę, „Ruch Biblijny i Liturgiczny” 43 (1990) nr 1-2, s. 39-40. 
udzielenie dwóch całkowicie odmiennych odpowiedzi na powyższe pytanie badawcze, to z praktycznego i pastoralnego punktu widzenia, tylko jedna odpowiedź powinna być udzielona przez kompetentną władzę kościelną. Byłoby wskazane, gdyby to biskup diecezjalny jasno ogłosił, jaka norma obowiązuje w diecezji w tej sprawie. Wierni mają prawo wiedzieć, jakiego zachowania się od nich oczekuje.

\section{Słowa kluczowe}

Kościól, liturgia, prawo kanoniczne, msza, obowiązek

\section{Abstract}

\section{Two precepts fulfilled on one Mass?}

The problem can be stated in the following question: Can a faithful fulfill two obligations of assisting at Mass on one Mass? The regulations are to be applied to answer the difficulty come mainly from two canons of 1983 Code of Canon Law: can. 1247 and can. $1248 \$ 1$. Clarifying the problem the paper describes the canons and interprets norms that come from them. The conclusion is that although law allows to give two quite opposite answers to the question, for practical and for pastoral reasons there must be only one obliging response given by the competent ecclesiastical authority. It would be appropriate if diocesan bishop clearly pronounced what behavior is obliging in his diocese in the matter. Christ's faithful have the right to know unmistakable what they are expected to do.

\section{Keywords}

Church, liturgy, canon law, Mass, obligation 